\title{
Chemical characteristics of snow in the region along the Sea of Japan
}

\author{
KAZUHide SATOW \\ Nagaoka College of Technology, 888 Nishikatakai, Nagaoka, Niigata 940, Japan
}

\begin{abstract}
The amount of acidity in precipitation has been measured in heavy-snowfall regions facing the Sea of Japan. The average $\mathrm{pH}$ value of precipitation measured throughout the year at Nagaoka was 4.80 during 4.5 years, 1987-92. During winter the $\mathrm{pH}$ value is lower and electric conductivity higher. The spatial distribution of chemical components in new-fallen snow was studied along a $55 \mathrm{~km}$-long sampling route. Results from four surveys showed that acidic snows have average $\mathrm{pH}$ values of 4.63-4.90. From the distribution of anion and cation concentration in new-fallen snow, it is concluded that strong northwest monsoons during winter bring an abundance of snow with salt components and many non-salt components from the Sea of Japan and also, possibly, from the Asian continent.
\end{abstract}

\section{INTRODUCTION}

Acid precipitation is one of the serious social problems in China as well as in Europe, North America and Canada. The survey of acid precipitation has begun in neighboring Korea and China (Kim, 1991; Quan, 1991). The serious environmental damages suffered directly from acid precipitation have not yet been reported in Japan, though acid rain has been observed also in Japan (Hara and others, 1990). It snows heavily, especially on the coast of the Sea of Japan in winter (December-March). However, the acid properties of snow in this area have not been investigated in detail; therefore the chemical features of snow have been analyzed.

At Nagaoka city in Niigata Prefecture, measurements of acid precipitation have been carried out throughout

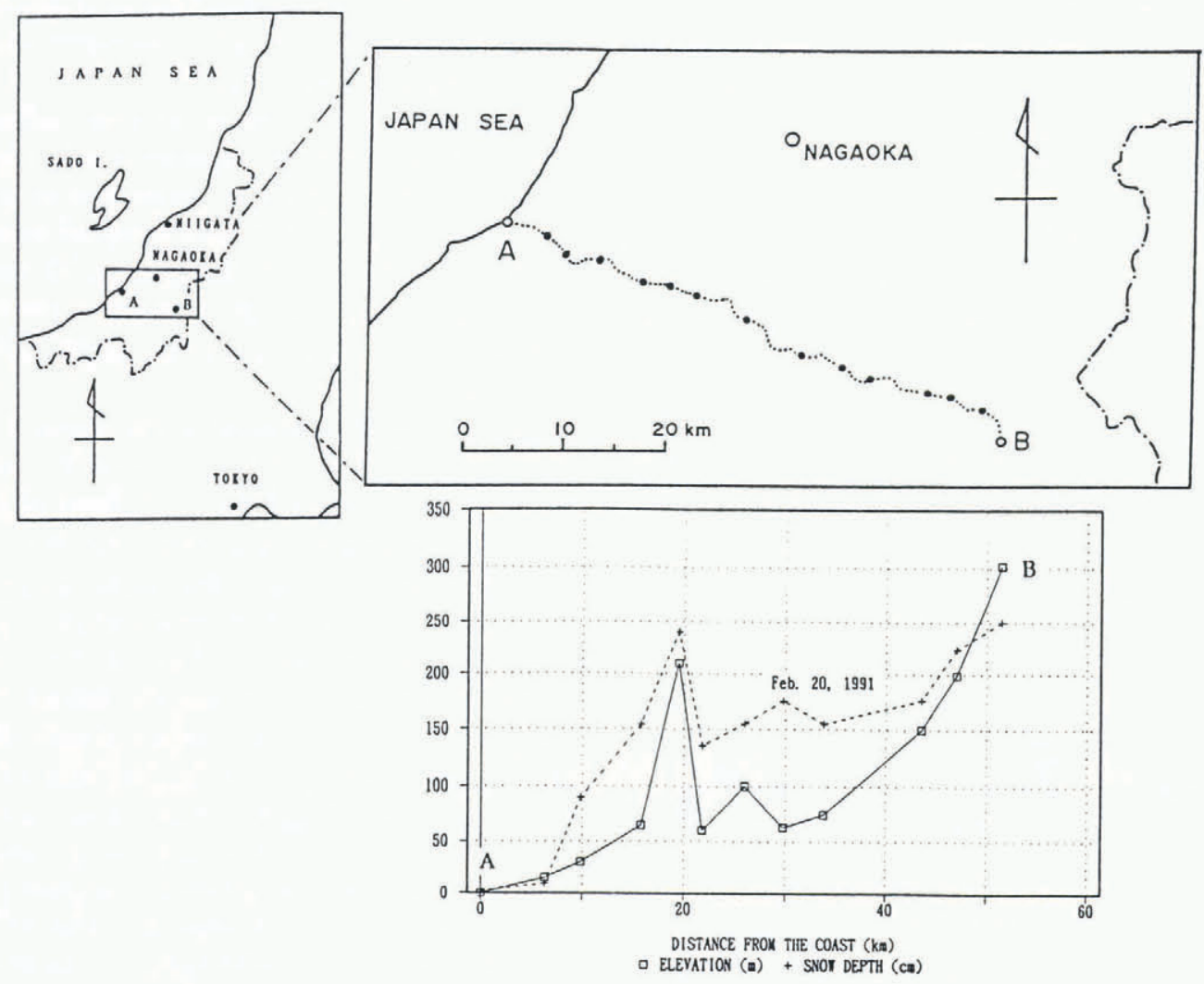

Fig. 1. Location map showing Nagaoka and the "investigation route" where snow was sampled. The lower part shows two profiles of elevation $(\mathrm{m})$ and of snow depth $(\mathrm{cm})$ along the route on 20 February 1991. 
the year. A precipitation sampling bottle was regularly replaced every day. Nagaoka is located at $37^{\circ} 26^{\prime} \mathrm{N}$, $138^{\circ} 54^{\prime} \mathrm{E}$ and $65.2 \mathrm{~m}$ a.s.l. In the average year, Nagaoka is covered with snow from December to March. The average maximum snow depth in winter has been about $140 \mathrm{~cm}$ for the past several decades.

In winter, the spatial distribution of acid snow has also been studied. Figure 1 shows the location of the observation area. The surface-snow samples along an "investigation route" were gathered in rinsed bottles. The chemical characteristics of precipitation in heavy-snowfall areas have been examined from these snow samples in my home laboratory.

The value of $\mathrm{pH}$ was measured in the laboratory using a $\mathrm{pH}$ meter (COM-11, Denki-Kagaku-Keiki Limited). The measurement of electrical conductivity (EC) was made using an electrical conductivity meter (DS-15, Horiba Limited). Anions and cations were analysed using a Shimazu Model HIC-6A ion chromatograph.

\section{ACIDITY MEASUREMENTS IN PRECIPITATION AT NAGAOKA}

Figures 2 and 3 show the change of $\mathrm{pH}$ and $\mathrm{EC}$ in precipitation at Nagaoka during the period December 1987-March 1992. The total number of samples over four years and five months was 705. A typical seasonal variation of $\mathrm{pH}$ can be seen, especially in 1989, showing lower $\mathrm{pH}$ values in winter and higher $\mathrm{pH}$ values in summer.

Winter values described here are for values gathered December-March, and summer values from AprilNovember. At Nagaoka, it can be said that the mean winter value of $\mathrm{pH}$ was 4.59 , the mean summer value was 4.98 , and the average value over 4.5 years was 4.80 . We can recognize that the acid precipitation falls year-round at Nagaoka. As for EC in close connection with ion concentration, the mean winter value was $88.9 \mu \mathrm{S} \mathrm{cm}^{-1}$, the mean summer value $48.5 \mu \mathrm{S} \mathrm{cm}^{-1}$; averaging at $58.1 \mu \mathrm{S} \mathrm{cm}^{-1}$.

The ratios of $\mathrm{Na}^{+}$to $\mathrm{Cl}^{-}$concentrations are almost the same values as for sea salt, and these concentrations become higher in winter. When the northwest seasonal

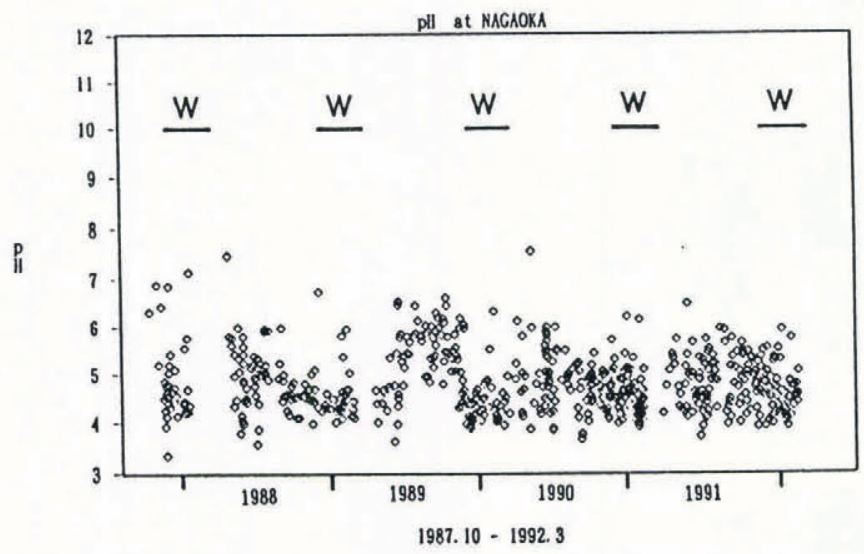

Fig. 2. pH variation in precipitation at Nagaoka during a period from October 1987-March 1992. " $W$ " indicates a winter period, December-March.

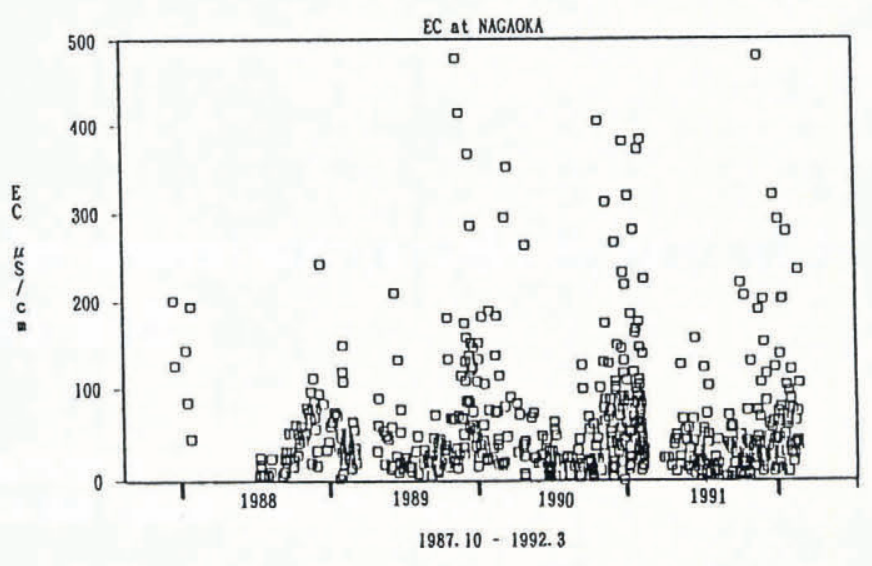

Fig. 3. Electric conductivity (EC) variation $\left(\mu \mathrm{Scm}^{-1}\right)$ during same period as Figure 2.

wind blows across the Sea of Japan where a warm current runs northward, a large amount of moisture is absorbed into the air during winter. As a result, this moisture precipitates as heavy snowfall in the regions facing the sea. Therefore, the high values of EC and ion concentration in snow during winter are caused by the containment of lots of sea-salt composition brought by the strong seasonal wind blowing toward Japan.

\section{SPATIAL DISTRIBUTION OF ACID SNOW}

To examine the spatial distribution of chemical features of snow, specimens of fresh snow were gathered along an investigation route extending for $55 \mathrm{~km}$ from the coast towards the inland, as shown in Figure 1. The elevation of this route rises from sea level at the coast to $300 \mathrm{~m}$ a.s.l. towards mountain ranges in the central part of Japan, with a hill along the route (Fig. 1). The depth of snow is closely related to the elevation, as shown in measurements for 20 February 1991 (Fig. 1).

The specimens of new snow were collected as follows. Following periods of uninterrupted snow, a freshly despoited snow layer was divided into an upper layer and a lower layer, which were sampled separately. Figure 4 shows examples of four analyses: A, 23 January 1990; B, 8 January 1991; C, 20 February 1991; and D, 22 February 1992. In each case the depth of new snow was $10-20 \mathrm{~cm}$.

The spatial distribution of $\mathrm{pH}$ shows that both $\mathrm{A}$ and B have a similar tendency, with only a small difference between the upper and the lower layer of new snow. The $\mathrm{pH}$ value decreases from the coast and then increases gradually towards inland, and again drops at the farthest area from the coast. The measurements of EC give the value below $50 \mu \mathrm{S} \mathrm{cm}^{-1}$, showing that the EC value decreases from the coast towards inland. In example C, the $\mathrm{pH}$ value of the lower layer of new snow was lower than that of the upper layer, and the EC value of the lower layer had higher values than that of the upper layer. This means that new snow at the beginning of snowfall has lower $\mathrm{pH}$ values and higher $\mathrm{EC}$ values than that towards the end of snowfall. The EC values of the lower layers were above $150 \mu \mathrm{S} \mathrm{cm}^{-1}$. In the case of D, EC distribution shows that the EC values of the lower layer were lower than that of the upper layer, in contrast to 

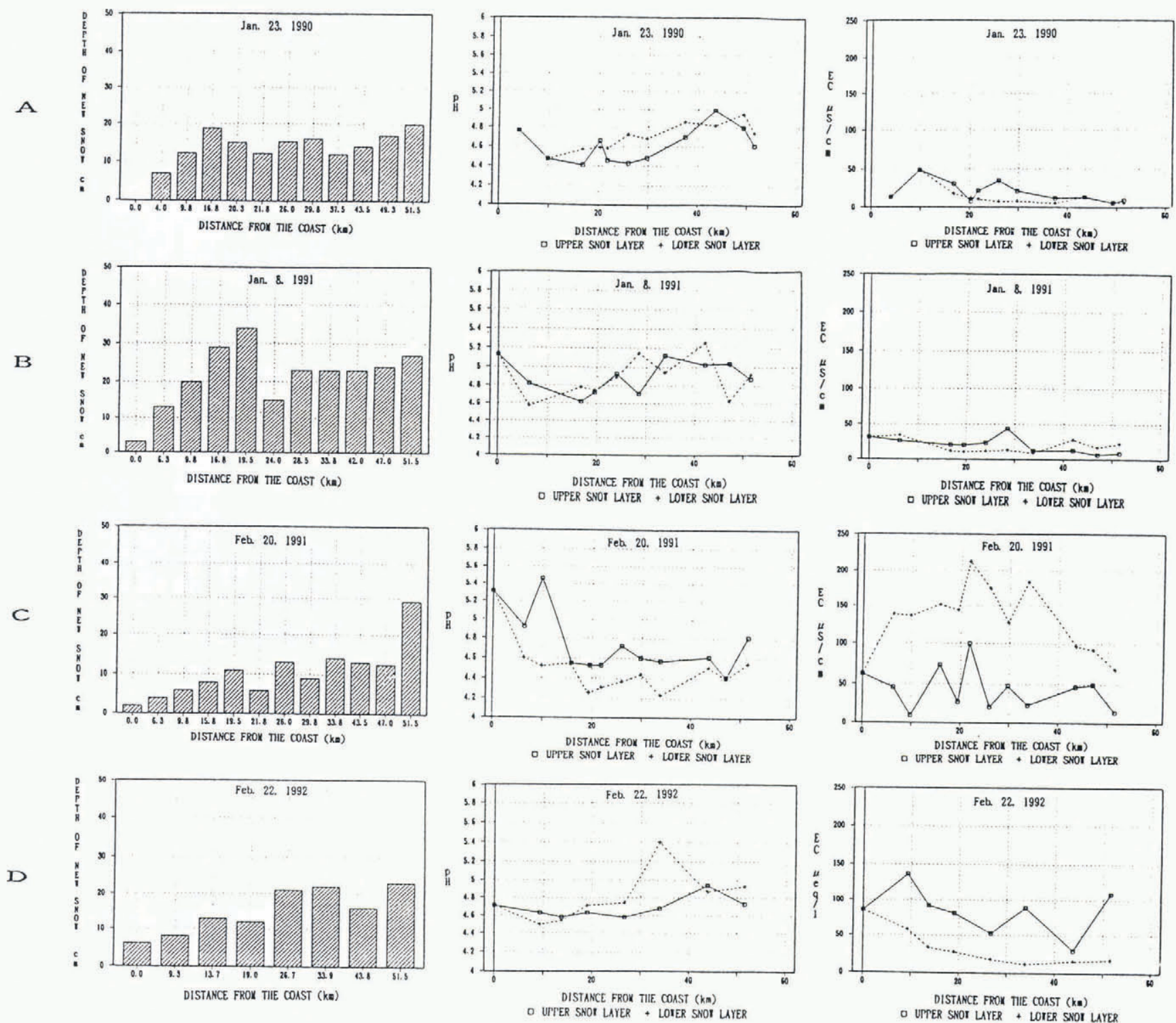

Fig. 4. Distribution of snow depth (cm), pH and $E C\left(\mu \mathrm{cm}^{-1}\right)$ of new snowfall along the "investigation route". $A, B$, $C$ and $D$ show measurements from 23 January 1990, 8 January 1991, 20 February 1991 and 22 February 1992, respectively. The left end of each graph is the coast ( $A$ in Fig. 1) and right end is furthest inland from the coast ( $B$ in Fig. 2). Solid lines in pH and EC variations indicate upper-layer values, and chain lines are lower-layer values in a newsnow layer.

example C. The EC values of the lower layer were smaller, with almost the same order as in $\mathrm{A}$ and $\mathrm{B}$, and those of the upper layers were $50-150 \mu \mathrm{S} \mathrm{cm}^{-1}$.

The average $\mathrm{pH}$ values were 4.66 for $\mathrm{A}, 4.90$ for $\mathrm{B}$, 4.63 for $\mathrm{C}$ and 4.74 for $\mathrm{D}$. Average EC values were $16.7 \mu \mathrm{S} \mathrm{cm}^{-1}$ (A), $19.3 \mu \mathrm{S} \mathrm{cm}^{-1}$ (B), $89.4 \mu \mathrm{S} \mathrm{cm}^{-1}$ (C) and $58.6 \mu \mathrm{S} \mathrm{cm}^{-1}$ (D). As mentioned above, new snow of the same snow depth has differences in chemical characteristics. Next the ion compositions of new snow were analyzed in examples B and C.

\section{Ion composition in example B, 8 January 1991}

Samples for upper snow layers and lower snow layers were analysed to determine major ion concentrations (anions: $\mathrm{Cl}^{-}, \mathrm{NO}_{3}{ }^{-}, \mathrm{SO}_{4}{ }^{2-}$; and cations: $\mathrm{Na}^{+}, \mathrm{NH}_{4}{ }^{+}$, $\mathrm{K}^{+}, \mathrm{Mg}^{2+}, \mathrm{Ca}^{2+}$ ) as shown in Figure 5. In the upper layers (Fig. 5A1 and $\mathrm{B} 1$ ), both anions and cations decrease from the coast towards inland except at one point, but $\mathrm{Ca}^{2+}$ becomes higher at the point farthest inland from the coast. With regard to lower layers, both anions and cations decrease from the coast towards inland and again increase (Fig. 5A2 and B2). To remove the influence of sea-salt components, non-sea-salt sulfate (nss$\mathrm{SO}_{4}{ }^{2-}$ ) concentration has been calculated according to the relationship

$$
\text { nss }-\mathrm{SO}_{4}{ }^{2-}=\mathrm{SO}_{4}{ }^{2-}-\mathrm{aNa}^{+}
$$

where $a$ is 0.119 , expressed in equivalents per litre. In the same manner, nss- ${ }^{+}$, nss- $\mathrm{Mg}^{2+}$ and $\mathrm{nss}-\mathrm{Ca}^{2+}$ were also calculated, using a to be $0.021,0.226$ and 0.043 , respectively. The distribution of non-sea-salt ions was almost uniform (Fig. 5C1, D1, C2 and D2). Only nss$\mathrm{Ca}^{2+}$ had a higher value in the upper snow at the farthest point inland from the coast (Fig. 5Dl). It is interesting that first-fallen snow has a higher concentration of sea-salt components both at the coastal area and at the area farthest inland from the coast, although the reason is not 

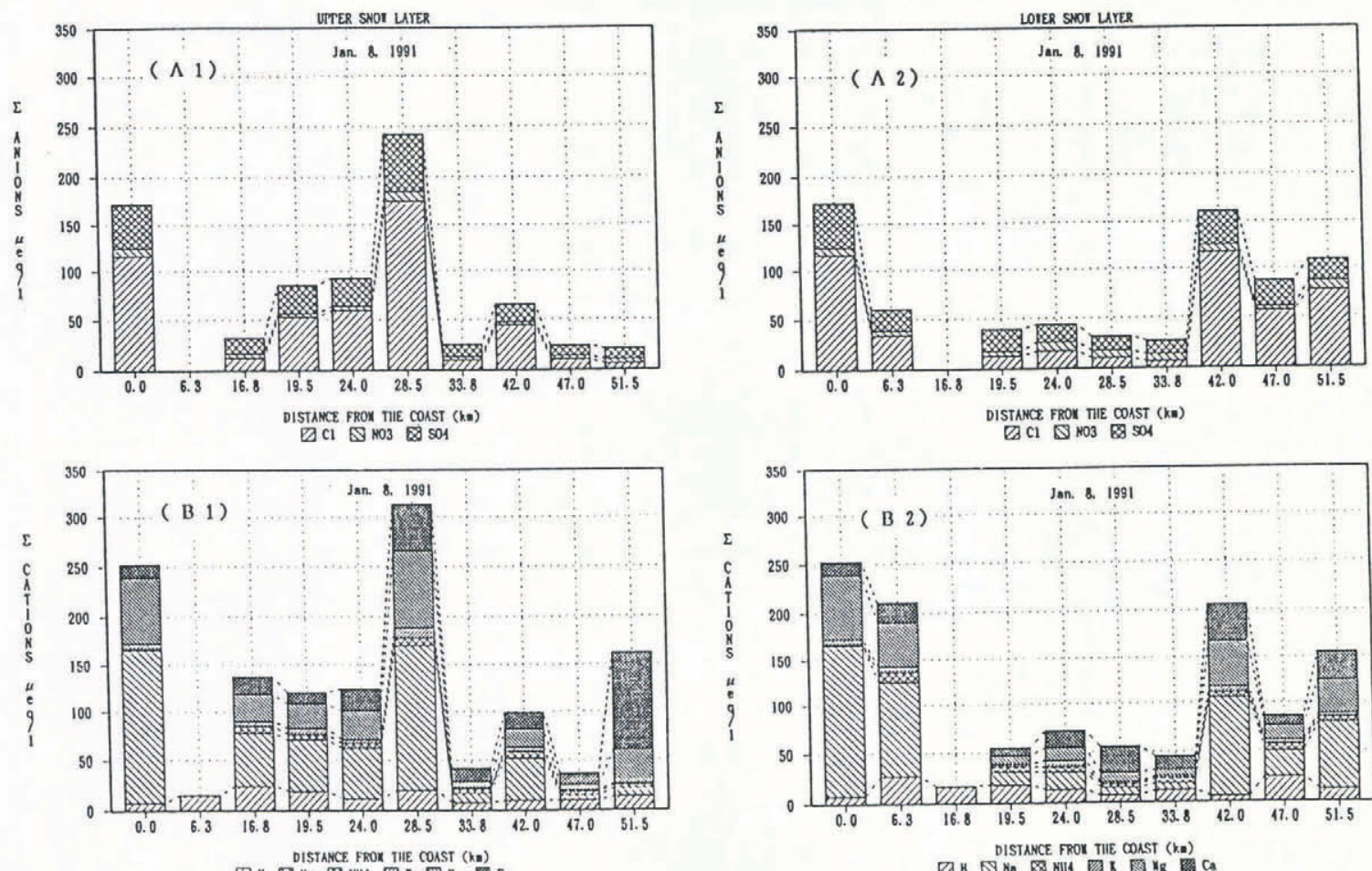

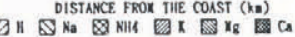
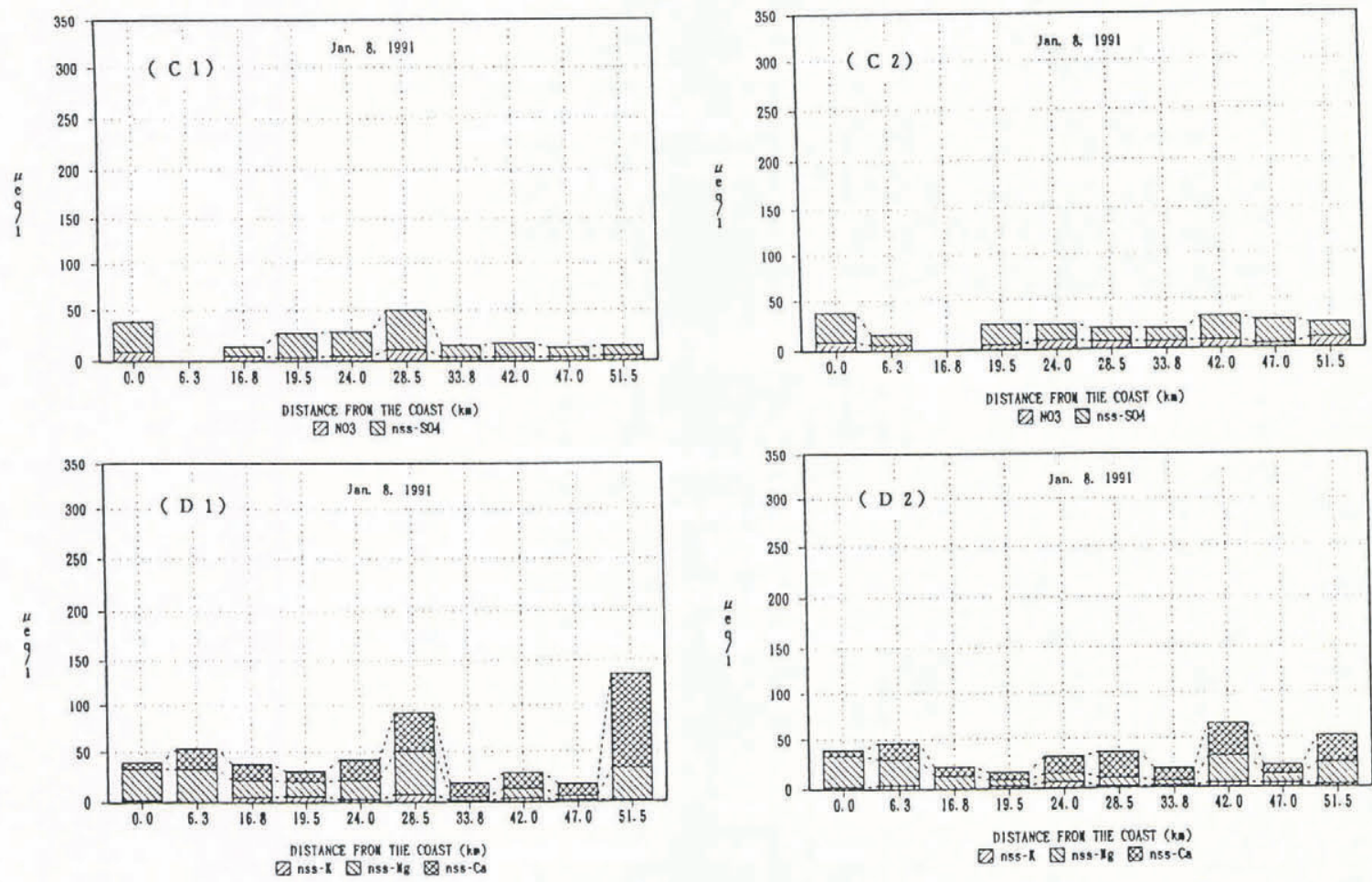

Fig. 5. Anions $\mathrm{Cl}, \mathrm{NO}_{3}^{-}$and $\mathrm{SO}_{4}{ }_{4}^{2-}$ concentrations ( $\mathrm{Al}$ and $\mathrm{A2}$ ), cations $\mathrm{H}^{+}, \mathrm{Na}^{+}, \mathrm{NH}_{4}^{+}, \mathrm{K}^{+}, \mathrm{Mg}^{2+}$ and $\mathrm{Ca}^{2+}$ concentrations (B1 and B2), non-sea-salt cations concentrations (nss- $\mathrm{K}^{+}, n s s-\mathrm{Mg}^{2+}$ and nss- $\mathrm{Ca}^{2+}: \mathrm{D1}$ and D2) of new snow sampled on 8 January 1991 along the observation route. Left graphs show the upper-layer values and right graphs the lower layer values in a new-snow layer. Unit: $\mu$ eq/l.

evident (Fig. 5A2 and B2). No close relation between $\mathrm{pH}$ and $\left(\mathrm{NO}_{3}^{-}+\right.$nss- $\left.\mathrm{SO}_{4}{ }^{2-}\right)$ is apparent.

\section{Ion composition in example C, 20 February 1991}

The spatial distribution of ion concentration in example $\mathrm{C}$ is shown in Figure 6. C has 3-12 times higher ion concentrations than B. It is remarkable that the concentrations of both anions and cations of first-fallen snow were about three times higher than those of lastfallen snow (Fig. 6Al-A2 and 6B1-B2). The lower layer contained many graupels (soft hailstones). This fact may be due to the result of the formation process of graupels in the atmosphere.

$\left(\mathrm{NO}_{3}{ }^{-}+\right.$nss- $\left.\mathrm{SO}_{4}{ }^{2-}\right)$ concentrations of non-sea-salt components at the coastal area were higher in first-fallen snow (Fig. 6C2). As shown in Figure 6D1 and D2, nonsea-salt components of cations were much higher (4 

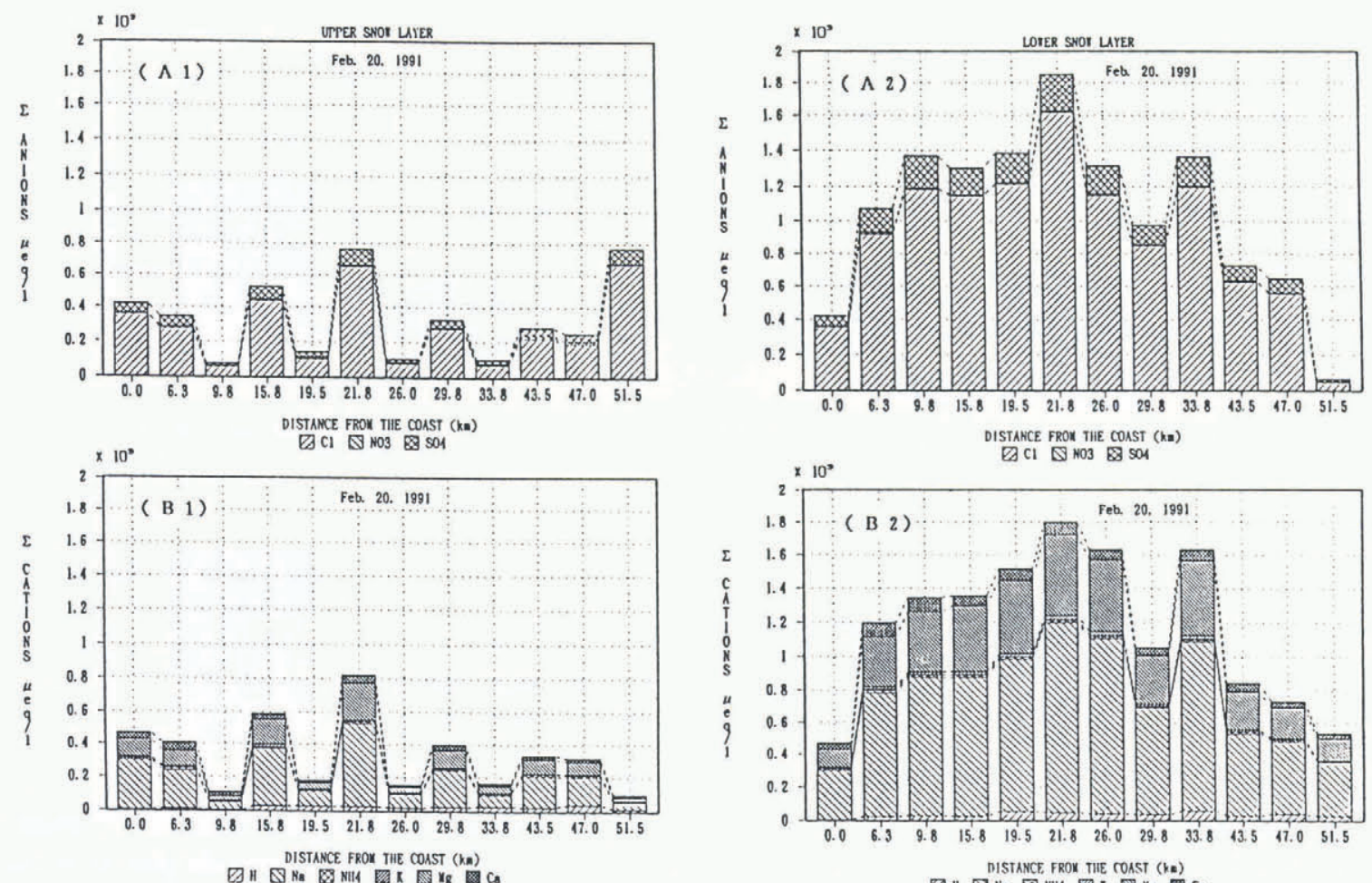

DISTANCE, FROK TIE COAST (Ke)

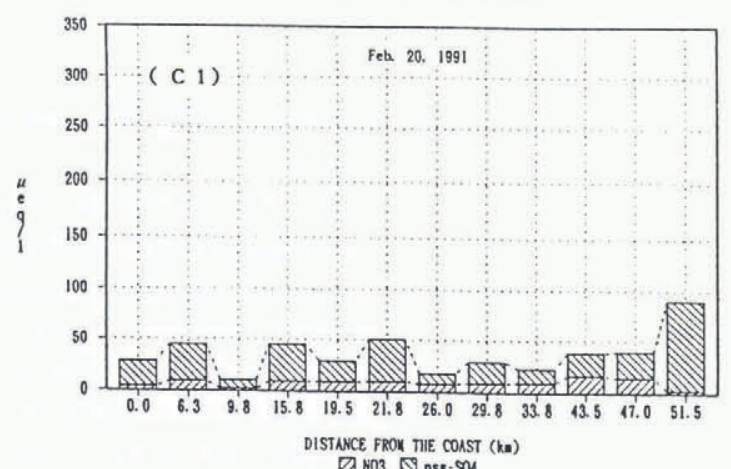

Q 211 -
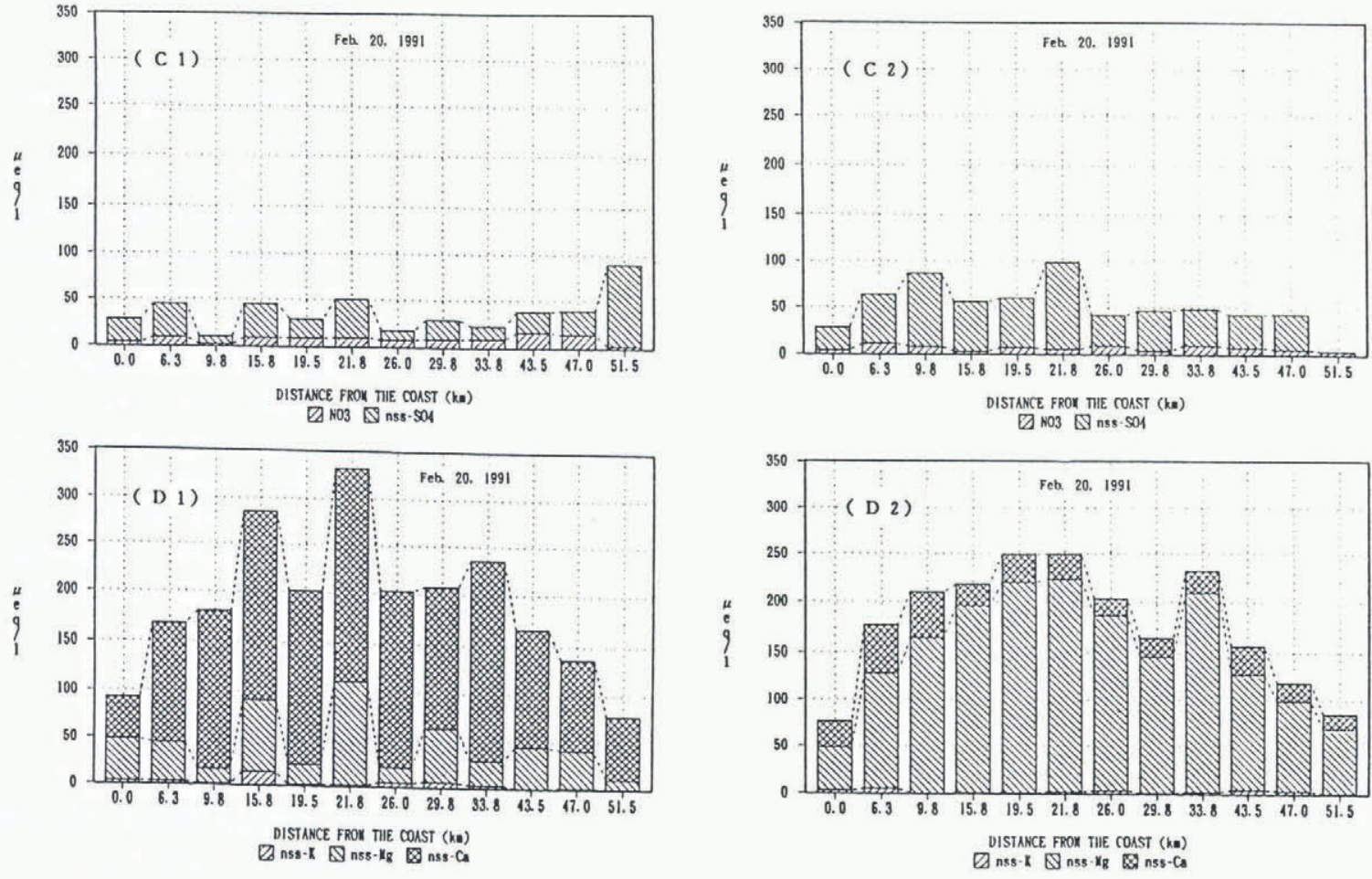

Fig. 6. Same as Figure 5 except for new snow sampled on 20 February 1991.

times), compared with example B. A striking feature is that $n s s-\mathrm{Mg}^{2+}$ concentration was higher in the first snowfall (Fig. 6D2) and nss-Ca ${ }^{2+}$ was higher in the last snowfall (Fig. 6D1). The reason is not evident, but it must be supposed that there are some influences of long-range transport of Asian desert dust (KOSA) particles (Iwasaka, 1990) and pollutant materials from the Asian continent, judging from weather conditions such as strong northwest winds during winter. There is not such a close relationship between $\mathrm{pH}$ and $\left(\mathrm{NO}_{3}{ }^{-}+\mathrm{nss}_{-} \mathrm{SO}_{4}{ }^{2-}\right)$ in this case.

Figure 7 shows mean anion and cation components for
$B$ and C. In the case of example B, mean anion components hardly differed in both first snowfall and last snowfall (Fig. 7A), but the total mean cation components, mainly $\mathrm{Ca}^{2+}$ concentration, increased during snowfall (Fig. 7B). On the other hand, mean anion and cation components in example $\mathrm{C}$ decreased very quickly during snowfall (Fig. $7 \mathrm{C}$ and $\mathrm{D}$ ).

A strong correlation between $\mathrm{Na}^{+}$and $\mathrm{Cl}^{-}$is observed in Figure 8A in the case of $\mathrm{C}$, showing a sea-water ratio. This figure also led to the conclusion that snowfall in this region is strongly influenced by northwest monsoon in winter. Both nss- $\mathrm{SO}_{4}{ }^{-}$and nss- $\mathrm{Mg}^{2+}$ were closely related 

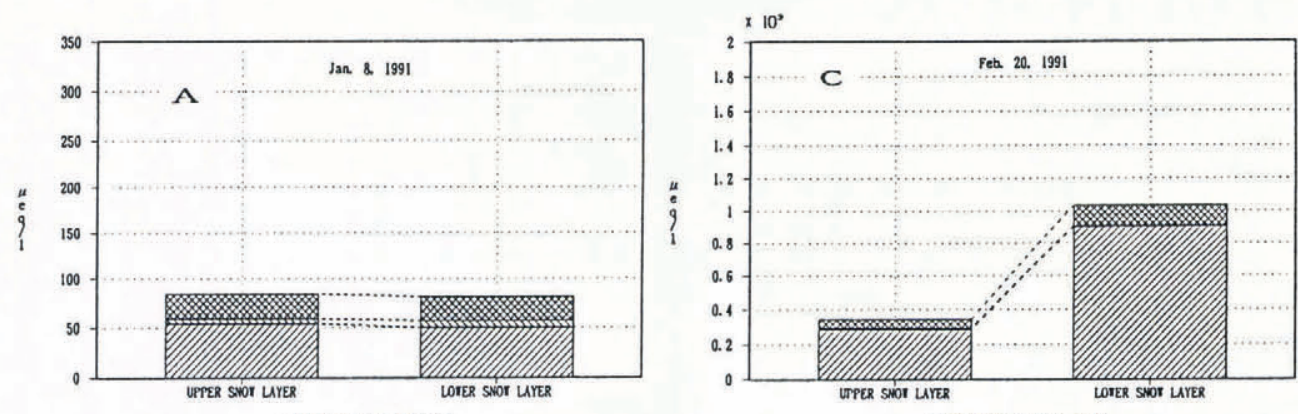

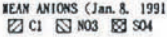

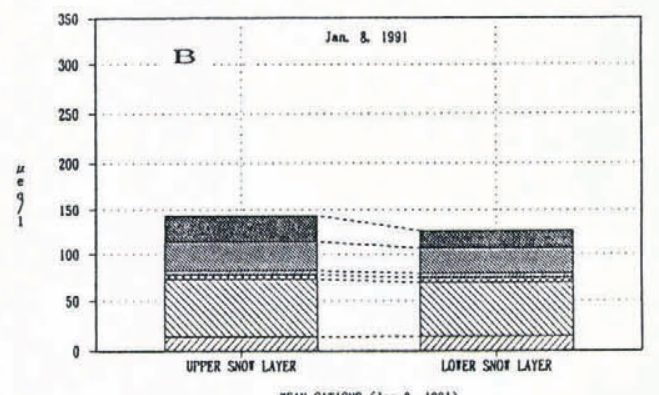

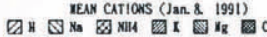

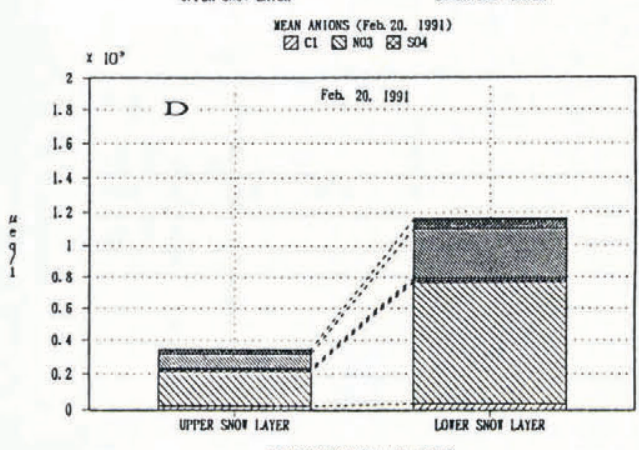

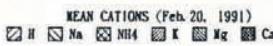

Fig. 7. The mean ionic balances (unit: $\mu e q / l$ ) in new snowfalls sampled along the "investigation route" on 8 January 1991 ( A, anions; B, cations) and on 20 February 1991 (C, anions; D, cations). Graphs on left show the upper layer and graphs on right the lower layer.
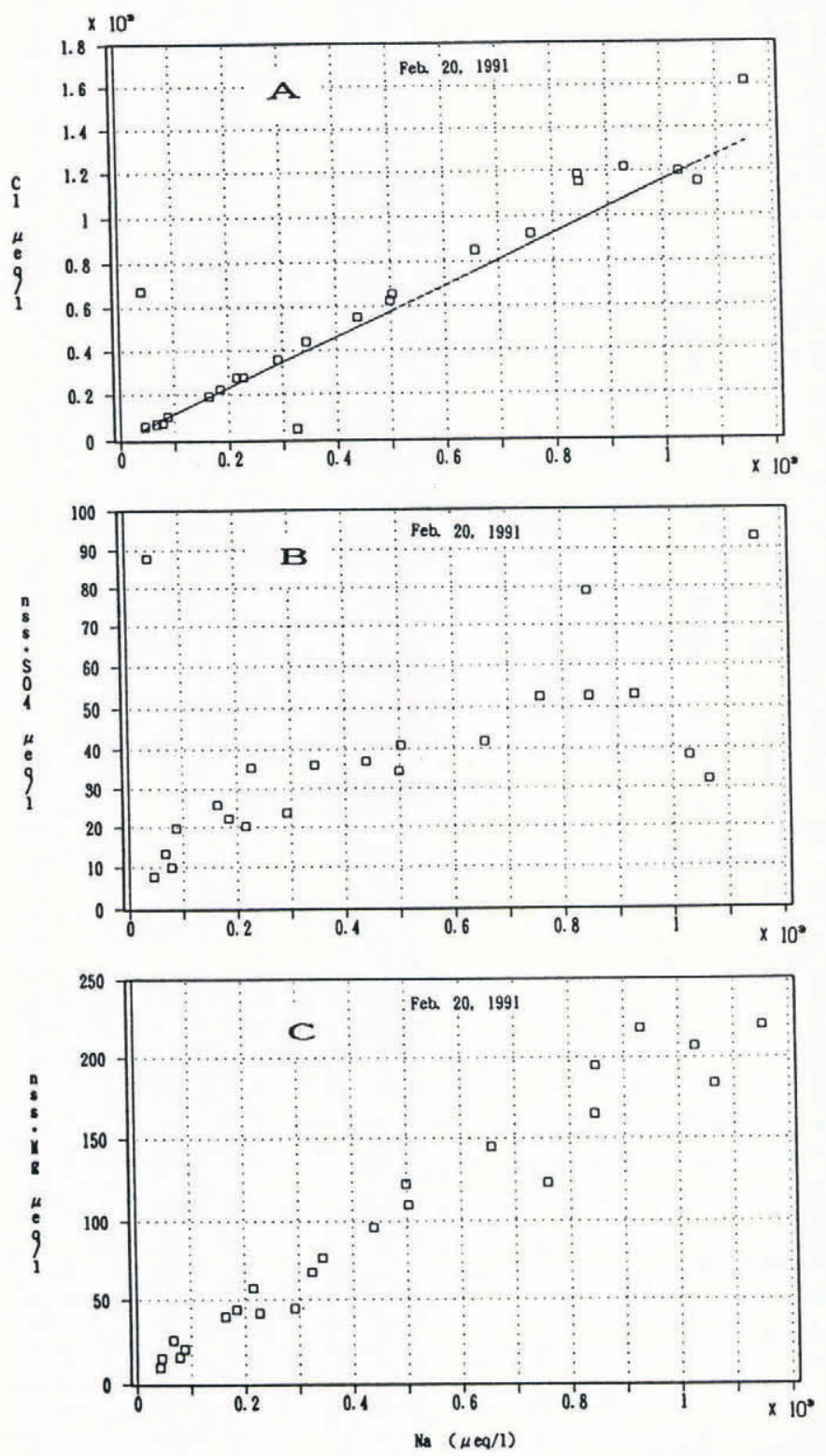

to $\mathrm{Na}^{+}$concentration (Fig. 8B and C). We can also find the same tendency in the case of $B$.

This indicates that when the northwest wind blows strongly, many sea-salt components from the Sea of Japan are transported toward Japan, along with many non-seasalt components from the Asian continent. Ueki and Iida (1989) reported that the $\mathrm{SO}_{4}{ }^{2-}$ and $\mathrm{Cl}^{-}$concentrations were higher in the snowfall than in the rainfall in summer season in Yamagata Prefecture, north of Niigata Prefecture. In Shimane, also facing the Sea of Japan, the average $\mathrm{pH}$ values in winter were $4.4-4.6$ owing to the increase of concentration rates of nss- $\mathrm{SO}_{4}{ }^{2-}$ and $\mathrm{NO}_{3}{ }^{-}$ higher than that of $\mathrm{NH}_{4}{ }^{+}$and nss- $\mathrm{Ca}^{2+}$ (Yamaguchi and others, 1989). These facts do not contradict the result of this study.

\section{CONCLUDING REMARKS}

Acidity in precipitation at Nagaoka has been examined throughout the year for the past 4.5 years. The average $\mathrm{pH}$ value is 4.80 and the average value in winter is lower. Electric conductivities in precipitation are higher in winter, and a lot of ionic compounds have been transported to the districts on the coast of the Sea of Japan.

Chemical characteristics of new-fallen snow in winter were analyzed along a line extending $55 \mathrm{~km}$ from the coast inland. The results of analyses for four new-fallen snows showed acidic snows in all cases with average $\mathrm{pH}$

$\triangleleft$ Fig. 8. Cl, nss-SO ${ }_{4}{ }^{2-}$ and nss- $\mathrm{Mg}^{2+}$ concentration ( $A$, $B$ and $C$ ) plotted against $\mathrm{Na}^{+}$concentrations of new-snow samples along the "investigation route" on 20 February 1991 (unit: $\mu e q / l$ ). The straight line in A shows a seawater ratio. 
values of 4.63-4.90. The strong northwest wind during winter has transported snow to Japan with many components of sea salt from the Sea of Japan along with many components of non-sea-salt, possibly from the Asian continent.

New-fallen snow, including many graupels, was lower in $\mathrm{pH}$ value and showed higher concentrations of both anions and cations. In this case, nss- $\mathrm{Mg}$ concentration was particularly higher, showing the effect of the mechanism of the graupel formation process.

\section{ACKNOWLEDGEMENTS}

I would like to express my sincere gratitude to my graduate students: Miss H. Okahata, Mrs. K. Kawachi, M. Sato, M. Taga, G. Tanabe, H. Yamakoshi, A. Kumakura, Y. Yamanaka, T. Kobayashi and T. Aoki, for their helpful assistance in the field and the laboratory. Many thanks are due to my wife, Kikuko Satow, for typing the manuscript. This study was partly aided by a Grant-in-Aid for Scientific Research Program (no. 02201103: led by E. Akitaya) of the Japanese Ministry of Education, Science and Culture.

\section{REFERENCES}

Hara, H. and 9 others. 1990. Report of acid precipitation in Japan. Working Group on the Assessment of Acid Rain Conditions in Japan. [In Japanese.]

Iwasaka, Y. 1990. Long range transport of Asian dust particle dust (KOSA) and its effect on the geochemical budget of soil particle. In The 2nd International Symposium on Acid Rain and Snow in the Circum-pan-Japan Sea Area. Kanazawa, Kanazawa University, ARSJSA 1990 Organizing Committee, 29-34.

Kim, H. K. 1991. Air pollutions of major cities in Korea. In The 3rd International Symposium on Acid Rain and Snow in the Circum-pan-Japan Sea Area. Kanazawa, Kanazawa University. ARSJSA 1991 Organizing Committee, 2347.

Quan, H. 1991. The present condition and the future subjects on acid precipitation in Chongquig area. In The 3rd International Symposium on Acid Rain and Snow in the Circum-pan-Japan Sea Area. Kanazawa, Kanazawa University. ARSJSA 1991 Organizing Committee, 721.

Ueki, K. and T. Iida. 1989. Acid precipitates in the district along the shore of the Japan Sea in Yamagata Prefecture. In International Symposium on Acid Rain and Snow in the Circum-Pan-Japan Sea Area. Kanazawa, Kanazawa University. ARSJSA 1989 Organizing Committee, 67-70.

Yamaguchi, K., M. Nakao, T. Tatano, F. Tanaka, M. Gomyoda and H. Hara. 1989. $\mathrm{pH}$ and ionic deposition of precipitations in Shimane. In International Symposium on Acid Rain and Snow in the Circum-Pan-Japan Sea Area. Kanazawa, Kanazawa University. ARSJSA 1989 Organizing Committee, 79-82.

The accuracy of references in the text and in this list is the responsibility of the author, to whom queries should be addressed. 